\title{
Tax discrimination in pension provision within the EU - The Safir, Danner and Skandia cases
}

Received: 24th July, 2003

\section{Naomi L'Estrange}

graduated in law from Clare College, Cambridge and took a Masters in European law at the Institute of European Studies in Brussels. She joined Herbert Smith in 1995 and since 1997 has worked as a solicitor in the pensions team, advising on a broad variety of pensions issues but maintaining a particular interest in European law aspects. She is a member of the Association of Pension Lawyers.

Abstract This paper summarises the jurisprudence of the European Court of Justice (ECJ) in relation to discriminatory tax provisions affecting the provision of pensions across national borders, and how an initial reluctance to interfere in fiscal autonomy has been gradually eroded, most recently in the Skandia case.

Keywords: discrimination; free movement of persons; freedom of establishment; tax relief; fiscal cohesion; deductibility of contributions

\section{Introduction}

Restrictions on free provision of pensions across national borders has been a significant impediment to the free movement of capital within the European Union, and as such has come under increasing focus from the European Commission. The recent Directive on institutions for occupational retirement provision, is a major political achievement which may have a significant impact on the investment patterns of European pension schemes; the main barrier to cross-border provision however, remains taxation.

Member states have jealously guarded Herbert Smith, Exchange House, Primrose Street, London EC2A 2HS, UK.

Tel: +44 (0)20 7374 8000; Fax: +44 (0)20 7374 0888; e-mail: naomi.l'estrange@ herbertsmith.com their autonomy to determine fiscal policy. The European Court of Justice (ECJ) has in the past, despite the best attempts of the Commission, been careful not to overstep the mark where conflict arises between member states' fiscal policy and the freedoms upon which the single market is based. So when it had to consider the Bachmann case (and parallel infringement proceedings against Belgium in January 1992) it shied away from a direct attack on the Belgian tax system. Eleven years later, much has changed. The Commission, following up on the indication in its Communication of April 2001, ${ }^{2}$ that restrictions on the free provision of pensions resulting from tax discrimination were a key target, is once more pursuing its infringement powers against a number of member states. Following the Safir, ${ }^{3}$ Danner, ${ }^{4}$ and Skandia ${ }^{5}$ cases it would seem that the Commission may have won over the Court to its way of thinking and that its prospects of success in pursuing member states for 
such discrimination have significantly increased.

\section{The background - Bachmann}

Mr Bachmann was a German national employed in Belgium. He complained that his contributions to health and life insurance policies in Germany were not deductible for tax purposes from his Belgian income, which they would have been had they been paid to an insurance company established in Belgium. In parallel, the Commission brought infringement proceedings against the King of Belgium under Article 169 (now 226) of the Treaty in respect of the same legislative provisions. ${ }^{6}$

The Court found in each case that the Belgian legislation concerned did amount to a restriction on the free movement of persons and the freedom to provide services contrary to Articles 48 (now 39) and 59 (now 49) of the Treaty.

However, the rules concerned could be justified by the need to preserve the cohesion of the applicable tax system. The argument, successfully made by the Belgian Government, was that the loss of revenue resulting from the deduction of pension and life assurance contributions from taxable income was offset by the taxation of the resulting pensions or capital sums. Where the insurer was established outside Belgium it would not be possible to ensure recovery of tax on payments made by the insurer. The cohesion of the Belgian tax system could not be ensured by a less restrictive measure.

The acceptance of a principle that member states could discriminate against providers established in other member states on the basis that they could not ensure that such payments would be properly taxed was, and has remained, a major barrier to the provision of services across borders. It is far simpler for fiscal authorities to control receipts from entities established within its borders than one outside it, so there is a great incentive for member states to discriminate in this way. Given the clarity and the apparent breadth of the Bachmann decision, how could the Commission seek to attack such discrimination?

\section{Wielockx}

The first breaches in the Bachmann defence, which gave the Commission the confidence it displayed in its 2001

Communication, came from the Wielock $x^{7}$ case in 1995. In that case, the Dutch government had sought to use the Bachmann argument to defend its refusal to allow a self-employed person resident in Belgium a tax deduction on a proportion of business assets allocated to a 'pension reserve' as it would have done for a Dutch resident. The argument failed because Holland's double taxation treaty with Belgium (on the Organisation for Economic Co-operation and Development (OECD) model) had not sought to maintain its right to tax pension benefits paid to those resident in Belgium. Although the Dutch Government would be unable to tax $\mathrm{Mr}$ Wielockx's pension unless he retired in Holland, there would be numerous Dutch workers who would pay tax on their pensions in Holland having received tax relief on their contributions in Belgium. The Dutch Government had therefore voluntarily exchanged precise internal fiscal cohesion for a more general supra-national cohesion based on reciprocity. Having done so, it could not justify this restriction which was in breach of Article 52 (now 43) of the Treaty of Rome.

The Court showed that a member state's ability to rely upon a Bachmann argument could be compromised by the 
content of its double taxation treaties. The Bachmann principle itself seemed to have survived.

\section{Safir}

The Safir case concerned the taxation of life assurance policies in Sweden. Life assurance companies in Sweden were charged a 'yield tax' based on the company's assets; premiums were not tax deductible but the proceeds were not subject to income tax. If premiums were paid to a company established outside Sweden they were subject to a 15 per cent 'premium tax' - however, this could be abated or full exemption granted if the insurance company concerned was subject to domestic revenue tax similar to the Swedish yield tax.

Jessica Safir, a Swedish national and resident, had taken out a life assurance policy with an English insurance company, Skandia Life Assurance Company Ltd. She applied for premium exemption and was granted a 50 per cent reduction, but this failed to satisfy her and the matter ultimately came before the ECJ in 1998 where she claimed that the provision was in breach of the freedom to provide services under Article 59 (now 49) of the Treaty.

On the face of it, the situation seemed similar to the Bachmann case, in that the provision in question made the payment of premiums to a company established elsewhere less favourable than those paid to a 'resident' provider. The Advocate General in his Opinion, ${ }^{8}$ sought expressly to distinguish the case from Bachmann, principally on the basis that in Bachmann there was direct balance between the refusal of a tax deduction on premiums and the tax exemption granted to the proceeds of the policy. In this case, the proceeds of the premium tax were not applied by the Swedish Government in granting any countervailing benefit to the policyholder.

The Court itself, however, did not see the need to apply this argument. It rejected Sweden's attempt to justify its provisions on the basis that the result was not proportionate to the aim. In particular, the fact that an exemption could be granted from the premium tax was of no assistance as the need for the policyholder to register and provide details of the domestic taxation applying to the insurance company concerned was itself a significant disincentive to choosing a provider established elsewhere. Perhaps the fatal blow to the fiscal cohesion argument was the fact that, prior to the Court hearing, Sweden had altered the applicable law so as to make it non-discriminatory between insurance companies established within and outside Sweden. It could hardly have hoped to succeed in arguing that this provision was vital to the cohesion of the Swedish tax system.

\section{Danner}

The Danner case concerned Finnish tax provisions which refused tax deductibility of pension contributions where the provider concerned was not established in Finland. The provision itself had only been introduced in 1996 and the draftsman clearly had Bachmann in mind - the Finnish Government had during the legislative process expressly stated that the provision was necessary because it would not be possible to ensure that pensions provided by foreign institutions would be taxed in Finland. ${ }^{4}$

Mr Danner was a doctor of Finnish and German nationality. He worked in Germany until 1977 when he moved to Finland. He then continued to make contributions to two German pension schemes. From 1996, with the entry into force of the new Finnish law, Mr Danner's contributions to the German 
arrangements ceased to be fully deductible. His complaint was referred to the European Court and was heard in autumn 2002.

Given the substantial similarity between this case and Bachmann, it is of little surprise that the Finnish Government again prayed in aid the Bachmann fiscal cohesion argument. The court found that a key element of the Bachmann case was the direct connection between the deductibility of contributions and the liability to tax on the proceeds of the policy. In this case there was no such connection, given that pensions paid by non-Finnish institutions were subject to income tax whether or not the contributions paid had themselves been deductible. The Court also applied the Wielockx principle given the existence of a double tax treaty between Finland and Germany, and gave short shrift to various arguments concerning the avoidance of fraud and tax evasion in reliance upon the ability of the member states to seek information from other member states under Directive $77 / 799 .{ }^{9}$

Practitioners were perhaps surprised to see, however, in the formal answer to the question from the Finnish Court, that the European Court did not go as far as the recommendation of the Advocate General and stated that the legislation was contrary to Article 59 of the Treaty of Rome (now 49) 'if the legislation does not at the same time preclude taxation of the pensions paid.... The Court therefore tied its decision firmly to the lack of the 'direct connection' required by Bachmann and left the Bachmann principle itself alive.

\section{Skandia}

The decision of the European Court in the Skandia case was given on 26th June, 2003. It concerned occupational pension insurance policies, which are policies taken out by Swedish employers to provide pension benefits to their employees. Essentially, whether or not the insurance provider was established in Sweden affects whether the policy is treated as a pension policy (where the contributions are deductible in the hands of the employer) or an endowment policy (where the contributions are not so deductible but the sums actually paid to the employee can be deducted by the employer at the time of payment). The effect on the employee is no different in each case. Skandia is a Swedish company employing (amongst others) $\mathrm{Mr}$

Ramstedt, a Swedish national resident in Sweden. Skandia offered Mr Ramstedt an occupational pension and determined that it wished to insure the pension through either its Danish, German or English subsidiary. It complained that its contributions to such a policy should be treated as pensions insurance and deductible immediately.

The situation here is essentially identical to that in Bachmann (save that one is only concerned with Article 49 $\mathrm{EC}$ and the free movement of workers is not relevant). The complainant wishes to receive the tax deduction immediately instead of waiting until the pension came into payment, as Mr Bachmann had to do. There was a 'balancing' tax relief, albeit in this case the ability of the company to deduct the payments at a later date rather than the pension itself being free of income tax. The complainant could not even say that the provision applicable to 'endowment' policies was necessarily less favourable than that applying to 'pension' policies — it might be more or less favourable depending on how large the pension paid was in comparison to the premiums.

The Court did not accept the argument that the direct correlation between deduction and taxation applied 
here. It found that there was no compensatory measure to offset the disadvantage to the employer of the delay in receiving the deduction. It therefore found that, since the effect of the legislation might be less favourable, the provision restricted the freedom of establishment and as such was contrary to Article 49 EC.

\section{Where are we now?}

This latest attempt to 'distinguish' the circumstances of Skandia from Bachmann would seem to leave virtually nothing in the 'fiscal cohesion' argument. The wording of the Skandia decision, which precludes differences in tax treatment which 'depending on the circumstances may be less favourable' could have been applied directly in Bachmann itself, as tax relief on pension payments might well, depending on the circumstances, be less favourable than tax relief on contributions. Other interesting aspects of the decision are the absence of any international element relating to the worker's employment, and the introduction of an 'occupational' element where previously the cases have related to private policies provided by insurance companies, an industry where the EU legislation is far more developed than other areas of retirement provision.

Spurred on in particular by the Danner decision, the Commission has commenced a number of infringement proceedings against member states in recent months. In particular, it has issued a formal request to Denmark concerning the non-deductibility of pension contributions paid to providers established outside Denmark, and has requested information from the UK and Irish Governments concerning their restriction on deductibility to contributions paid to arrangements taking a particular form and having an administrator situated in that country.

Despite the lengthy delays involved in proceedings before the European Court, and its expressed unwillingness to legislate by the back door as a result of artificial 'test' cases, the recent jurisprudence of the Court in respect of tax discrimination shows that it has lost any fear of addressing matters of direct taxation. The Court may yet be the most effective weapon for the Commission in its attempts to achieve pan-European pension provision.

\section{References}

1 Case C-204/90 Bachmann v Belgium [1992] ECR I249.

2 Communication from the Commission to the Council, the European Parliament and the European Economic and Social Committee, 'The elimination of tax obstacles to the cross-border provision of occupational pensions', 19/4/01 COM (2001) 214.

3 Case C-118/96 Safir v Skattemyndigheten I Dalarnas Lan [1998] ECR I-1897.

4 Case C-136/00 Rolf Dieter Danner [2002] ECR I-8147.

5 Case C-422/01 Forsakringsaktiebolaget Skandia and Ola Ramstedt $v$ Riksskatteverket (not yet reported).

6 Case C-300/90 Commission of the European Communities v Kingdom of Belgium [1992] ECR I-305.

7 Case C-80/94 Wielockx v Inspecteur der Directe Belastingen [1995] ECR I-2493.

8 Opinion of Advocate General Tesauro in the Safir case, para. 37.

9 Council Directive 77/799/EEC OJ 1977 L336. 